\title{
DAMAGE TO FOUNDATIONS OF RAILWAY STRUCTURES
}

\author{
DAIZO KARUBE ${ }^{\mathrm{i})}$ and MAKOTO KIMURA ${ }^{\mathrm{ii})}$
}

\begin{abstract}
An outline of the results of investigation into the damage and reconstruction of foundations of railway structures is presented in this paper prepared by committee members of the Japanese Geotechnical Society. The foundations of elevated bridges near a quay or a river levee moved and inclined due to the movement of the surrounding subsoils. Mat foundations for an elevated rigid frame bridge did not undergo damage whereas meshed cracks or complete shear failures were found in the piers below the ground surface. Cracks were found frequently at the top of the pile foundations for bridges supported on one-pier.
\end{abstract}

Key words: alluvial deposit, case history, earthquake damage, foundation, levee, pile, quay, railroad, shallow foundation (IGC: E8/H6)

\section{INTRODUCTION}

The damage of the 1995 South Hyogo Prefecture earthquake was mainly concentrated in a strip area between Osaka and Kobe where, as shown in Fig. 1, four railways with a high transportation capacity run. JR-SanyoShinkansen which is a long distance and rapid transit system with double tracks transports 110,000 passengers/ day between Osaka and Kobe. The JR-Tokaido and Sanyo line (four tracks), Hankyu line and Hanshin line transport $330,000,210,000$ and 140,000 passengers/day respectively. In addition, many other local railway service systems and subways also exist, such as the Sanyo line connected to western Kobe, the Kobe line, Kobe subway and Port-Liner and Rokko-Liner.

On the day when the earthquake occurred, all these railway networks stopped, although, by January 23, railway service was resumed as far as $20 \mathrm{~km}$ east from San-nomiya (the center of Kobe), $10 \mathrm{~km}$ west of the center and the Northern Rokko Mountain. The railways within Kobe and the JR-Sanyo-Shinkansen were destroyed at many locations. The length of time to rehabilitate and repair this damage was estimated to be at least 4 months.

Another mass transportation system between Osaka and Kobe consists of elevated highway which also underwent extensive damage. Since the expressway structures are much larger than those for railways and damage was more serious, it will take more time to repair them. As a result, a major effort was expended for the rehabilitation of the railways.

On April 1st, the JR-Tokaido and Sanyo line first resumed service after 2.5 months shut down. Other railways except for the Port-Liner and Rokko-Liner were also repaired during June. The resumption of service was 2 months earlier than the initially predicted. There are several reasons why the rehabilitation of the railways was completed so quickly. One reason is that; if the superstructure could be used without repair or with only a little repair, then the check of its foundation was not detailed. Even if the superstructure was damaged, the foundation footing was generally found to be sound. If however the damage to the superstructure was known to be caused by the damage to its foundation, then the foundation had to be repaired first. The reason why the recovery of Port-Liner and Rokko-Liner lasted until the end of July was that the repair of the foundations took much longer.

The main railroad structures are embankments, elevated bridges and river crossing bridges. The rivers that run though the earthquake damage area are the Muko river and Yodo river. The only river crossing bridge that underwent damage was the Muko river bridge of the JRSanyo-Shinkansen. Based on the pattern, it is hard to relate the damage to its foundation. The railway embankments were damaged at many locations which have been reported elsewhere. In this report, major attention is paid to the treatment of railway foundations.

i) Professor, Kobe University, Rokkodai 1-1, Nada-ku, Kobe 657.

ii) Associate Professor, Kyoto University, Kyoto 606-01.

Manuscript was received for review on August 18, 1995.

Written discussions on this paper should be submitted before August 1, 1996, to the Japanese Geotechnical Society, Sugayama Bldg. 4F, Kanda Awaji-cho 2-23, Chiyoda-ku, Tokyo 101, Japan. Upon request the closing date may be extended one month. 


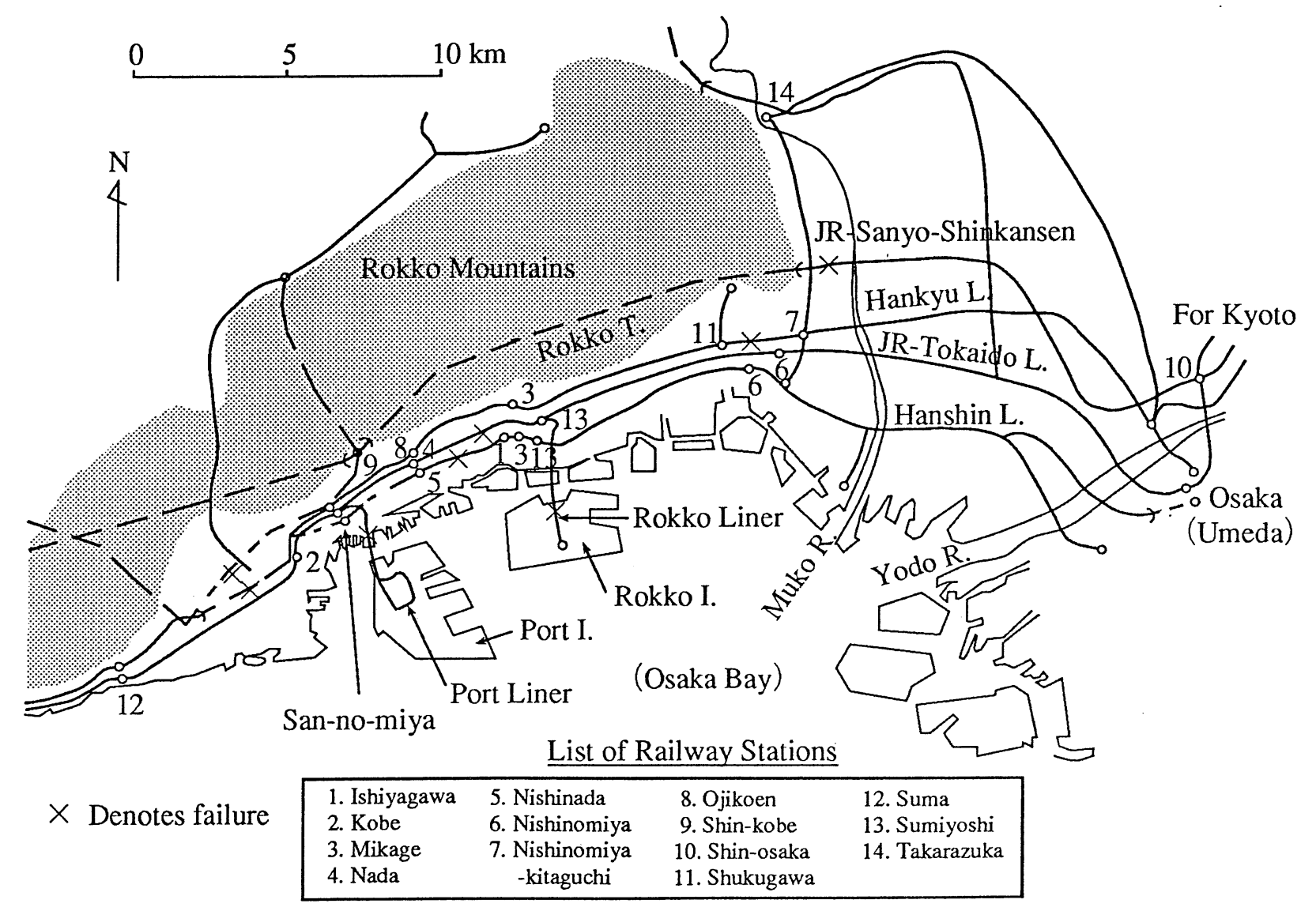

Fig. 1. Railway map of Kobe area and vicinity

\section{ROKKO-LINER}

Rokko-Liner is a medium size railway system connecting the man-made Rokko Island and the mainland, constructed in 1990. The side span of the bridge connecting the island and mainland fell down on the island side during the earthquake, which is thought to be the result of the movement of the revetment towards the sea; observed to be about $1.0 \mathrm{~m}$. Since at the same time the backfill behind the revertment also moved towards the sea, the caisson foundation of the bridge pier inclined. Figure 2 shows the displacement of the caisson and the design of foundation repair. The deformed caisson was enclosed with steel pipe sheet piles and is being reconstructed. Photograph 1 shows the reconstruction site taken looking toward the island from the revetment. The lower part of the photo shows the new foundation under construction with the upper part being the section of the elevated bridge.

The main rail of Rokko-Liner on the mainland is located on the west side of the Sumiyoshi river. The railway bridge is made of steel, supported by a single pier, 7 18 $\mathrm{m}$ in height, with square-shaped steel sections. The foundation is an independent footing, with a depth close to the bottom of the river. During the earthquake, the pier inclined one degree below the horizontal. Some piers buckled $1 \sim 2 \mathrm{~m}$ above the ground surface.

\section{PORT-LINER}

Port-Liner is a medium size railway system connecting the man-made Port Island located in Kobe Harbor and the mainland. It was constructed in 1981. After the line crosses the bay on a large bridge, it is supported on an elevated bridges with single piers or gate-type piers on the jetty extended from the mainland. The foundation of the bridge is an independent footing with a depth of about 3 $\mathrm{m}$. An old masonry jetty is located below the bottom of the footing. During the earthquake, the piers of the bridge inclined several degrees in a westerly direction. In order to reconstruct the foundation, the cast-in-place piles were installed through the old masonry jetty outside of the existing footing and their pile heads were joined with a new raft. Figure 3 shows the reconstruction of the station foundation on the jetty.

The elevated bridge between this jetty and the San-nomiya terminal (except immediately adjacent to this terminal) are mainly supported by a single pier with a pile group foundation. Since elevated bridges which did not undergo serious damage to the superstructure existed, several piles below those sound superstructures were investigated and the piles were found to be almost cracked. In addition, the load acting on the foundation increased because of the reinforcement work of the upper part. For this reason, it was necessary to rehabilitate these pile foundations. The method of repairing these foundation 

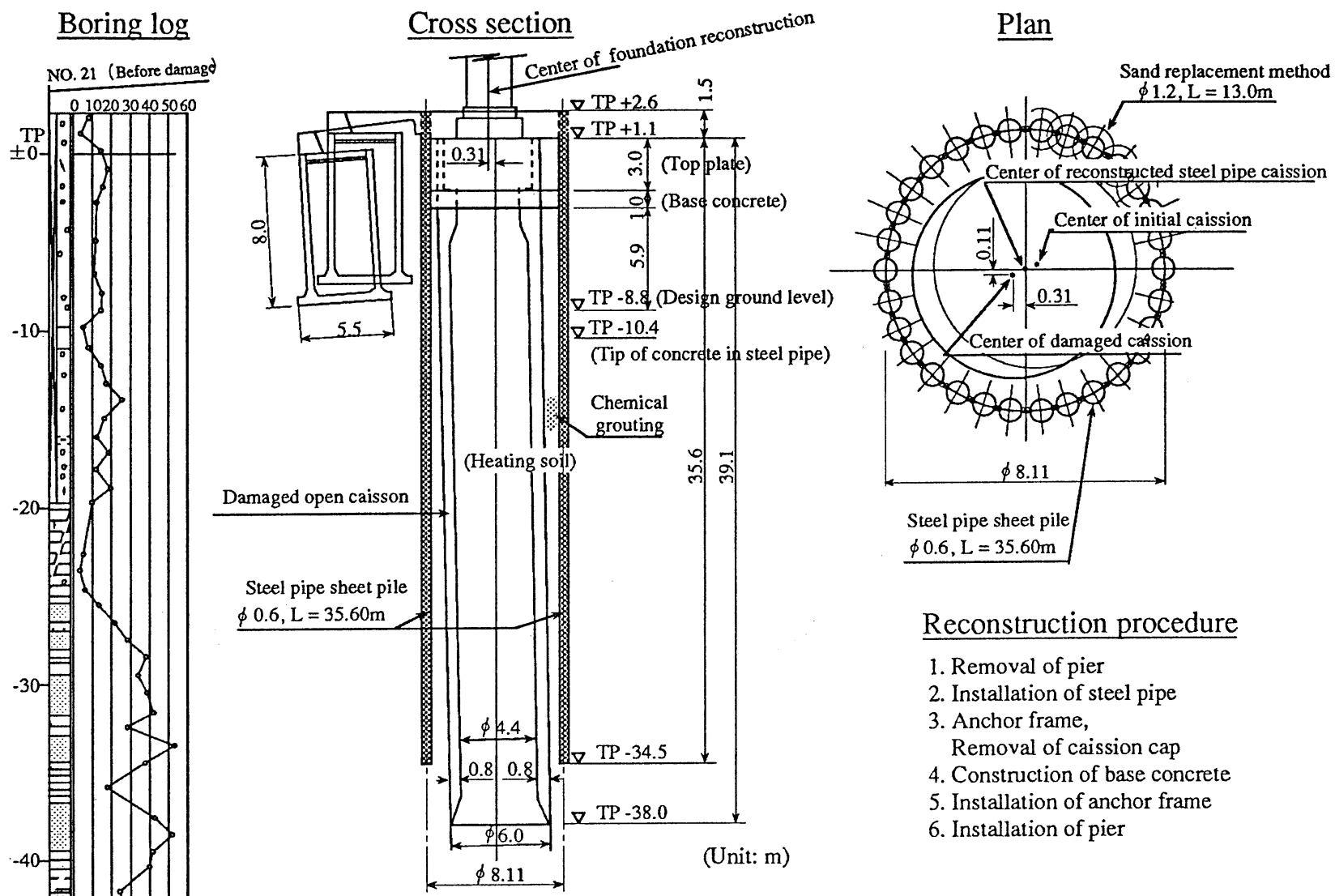

$\underline{\text { Reconstruction procedure }}$

1. Removal of pier

2. Installation of steel pipe

3. Anchor frame,

Removal of caission cap

4. Construction of base concrete

5. Installation of anchor frame

6. Installation of pier

Fig. 2. Displacement of caisson and the design of repair to foundation (Rokko-Liner).

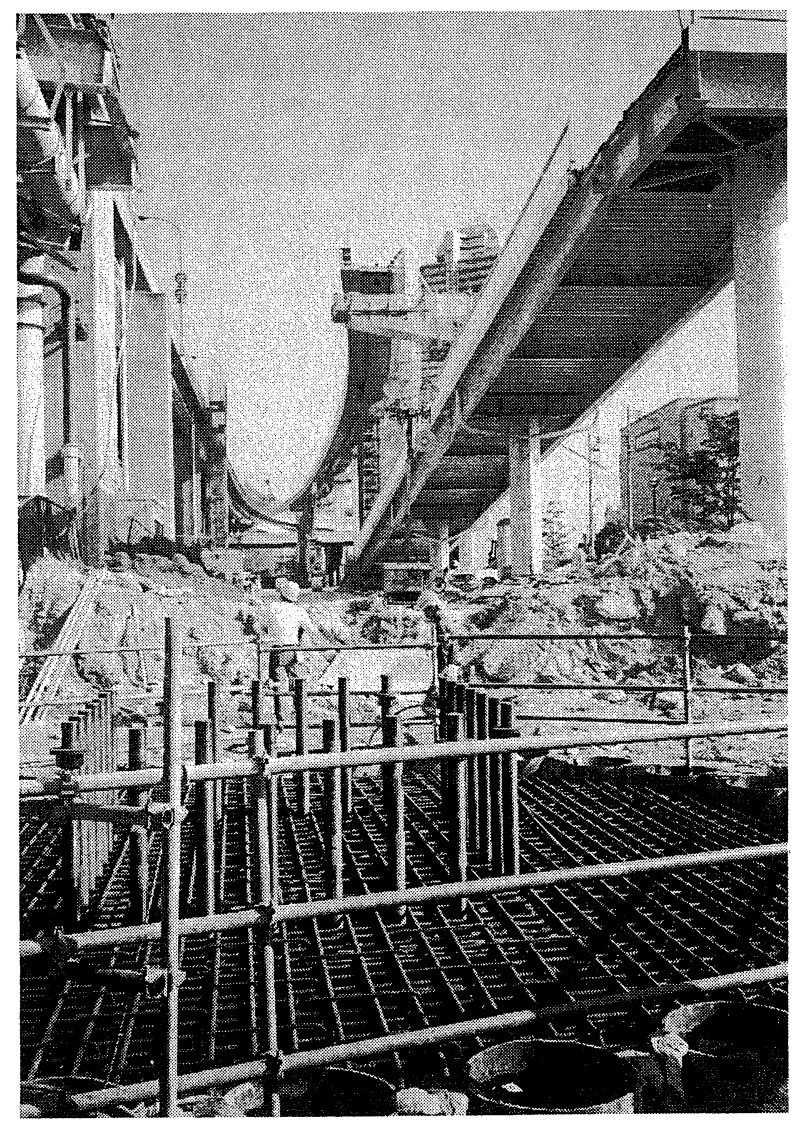

Photo. 1. New foundation under construction (Rokko-Liner) was also carried out by constructing cast-in-place piles along the outside of the foundation.

\section{HANSHIN RAILWAY}

The Hanshin railway underwent little damage in approximately a $3 \mathrm{~km}$ area from San-no-miya (the center of Kobe) to the east, constructed in tunnel and open excavated trench. The next $3 \mathrm{~km}$ to the east, the railway is a $2 \mathrm{~km}$ elevated "Nisinada Ishiyagawa Bridge" constructed in 1968 and an embankment. In this section, almost all structures, no matter what kind of structure it may be, experienced extensive damage. One of the main train storage yards "'Ishiyagawa Garage (elevated structure)", located in this area was completely destroyed. However, the next $1.2 \mathrm{~km}$ elevated bridge (Mikage $\sim$ Sumiyoshi), constructed in 1929, although ancient, was not damaged at all. It is worthwhile in future to investigate the reasons for such contrast.

The general structure of the elevated bridge that failed in the area of Nisinada Ishiyagawa is a RC four-span rigid frame. The length of each span is $8 \mathrm{~m}$. The foundation, as shown in Fig. 4, is a footing connected with underground beams in the transverse direction. The subsoils below the foundation are mainly silt with gravel. The ground water level may reach the footing at some high level. All foundations were investigated by excavating soil to down the bottom of the footing and checking 
visually. As a result, only a hair crack was found in a few footings while meshed cracks were found in the piers below the ground surface as shown in Photo. 2. In addition, although it was few case, complete shear failures were also observed as shown in Photo. 3. Although the degree of damage and the occurrence frequency below ground was quite small compared with the above ground, the primary factor for damage (geological structure, the location in the rigid frame, condition damage of the superstructure etc.) should be clarified by statistical analyses.

For repair, cracks in the foundation were filled with resin mortar. All railway bridge piers were coated with 9 $\mathrm{mm}$ or $6 \mathrm{~mm}$ steel plate with non-contract mortar along the entire length. In addition, for the structure below ground, the outer layer of the steel plate was covered with reinforced concrete. In addition, the Ishiyagawa Garage will be reconstructed by the new steel rigid frames with new installed piles.

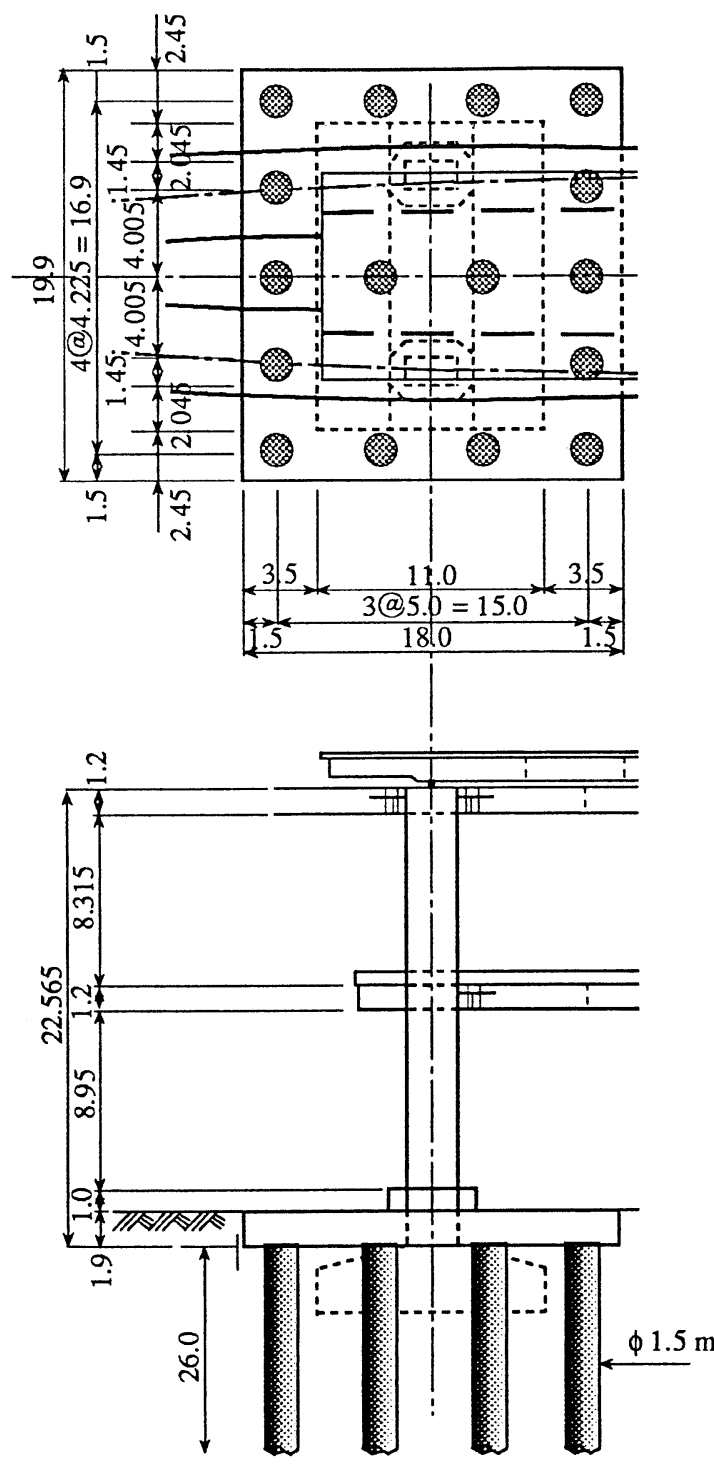

\section{JR-TOKAIDO AND SANYO LINE}

Almost all of the JR Line in the Kobe city (Sumiyoshi $\sim$ Nada and Nada $\sim$ Takatori) consists of elevated bridges with four tracks arranging in two rows of double tracks. Within about $10 \mathrm{~km}$ in central Kobe city (Nada Takatori) the elevated bridges were constructed between 1920 1938. They withstood World

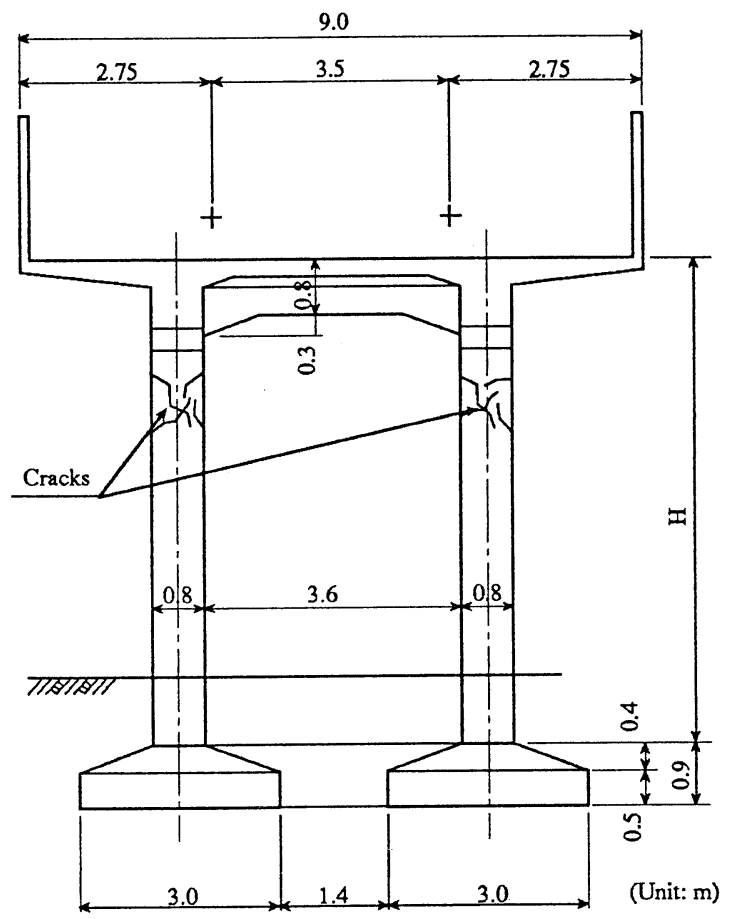

Fig. 4. Mat foundation with underground beams (Hanshin railway, Nishinada $\sim$ Mikage section)

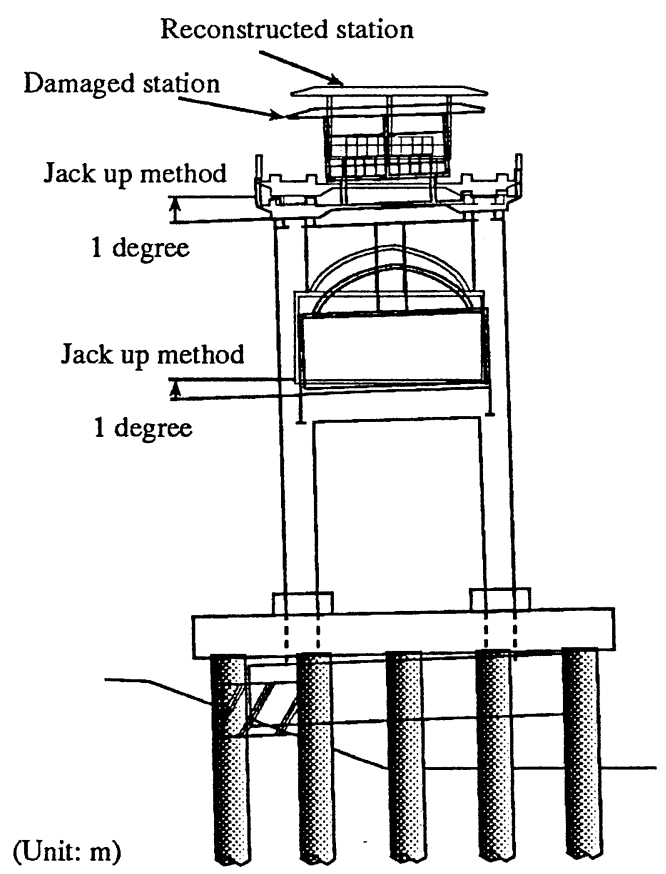

Fig. 3. Reconstruction of the station foundation for the Port-Liner jetty 


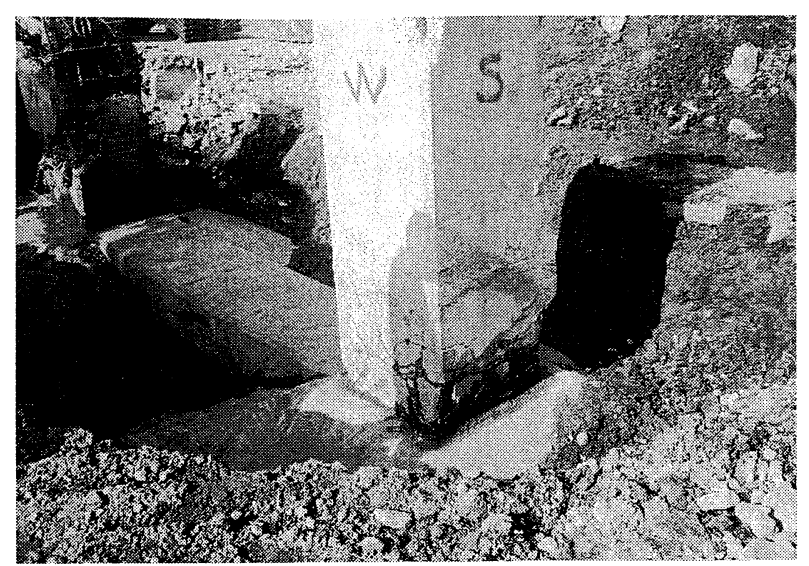

Photo. 2. Meshed cracks piers below ground surface (Hanshin railway)

War II and flood since their completion and underwent few damage during this earthquake. The bridge in the next $3.5 \mathrm{~km}$ area to the east from Sumiyoshi to Nada in-

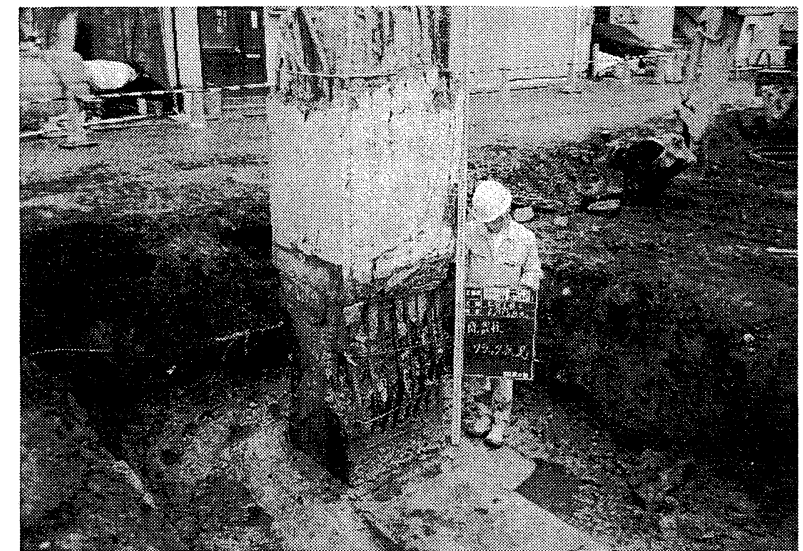

Photo. 3. Complete shear failures piers below ground surface (Hanshin railway)

cluding an intermediate station (Rokko-michi) however failed. Figure 5 shows the typical structure of the old and new elevated bridges. Both are continuous RC rigid (a)

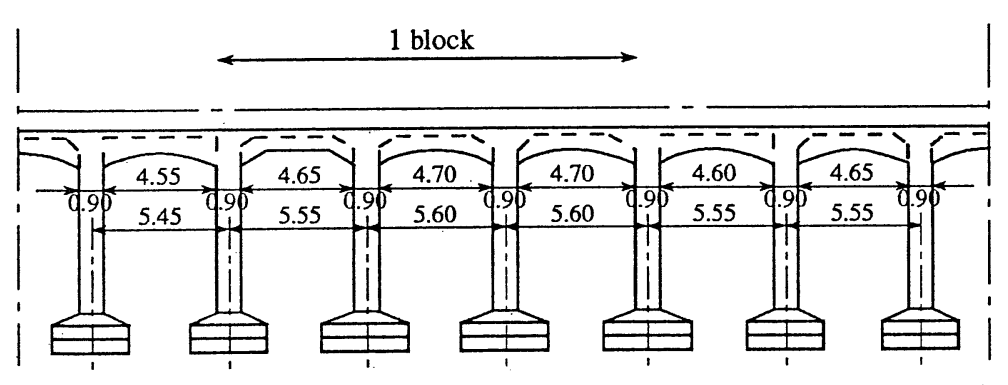

(Unit: $\mathrm{m}$ )
Elevation

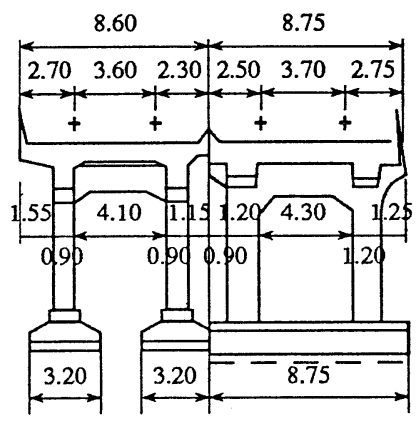

(b)

Elevation

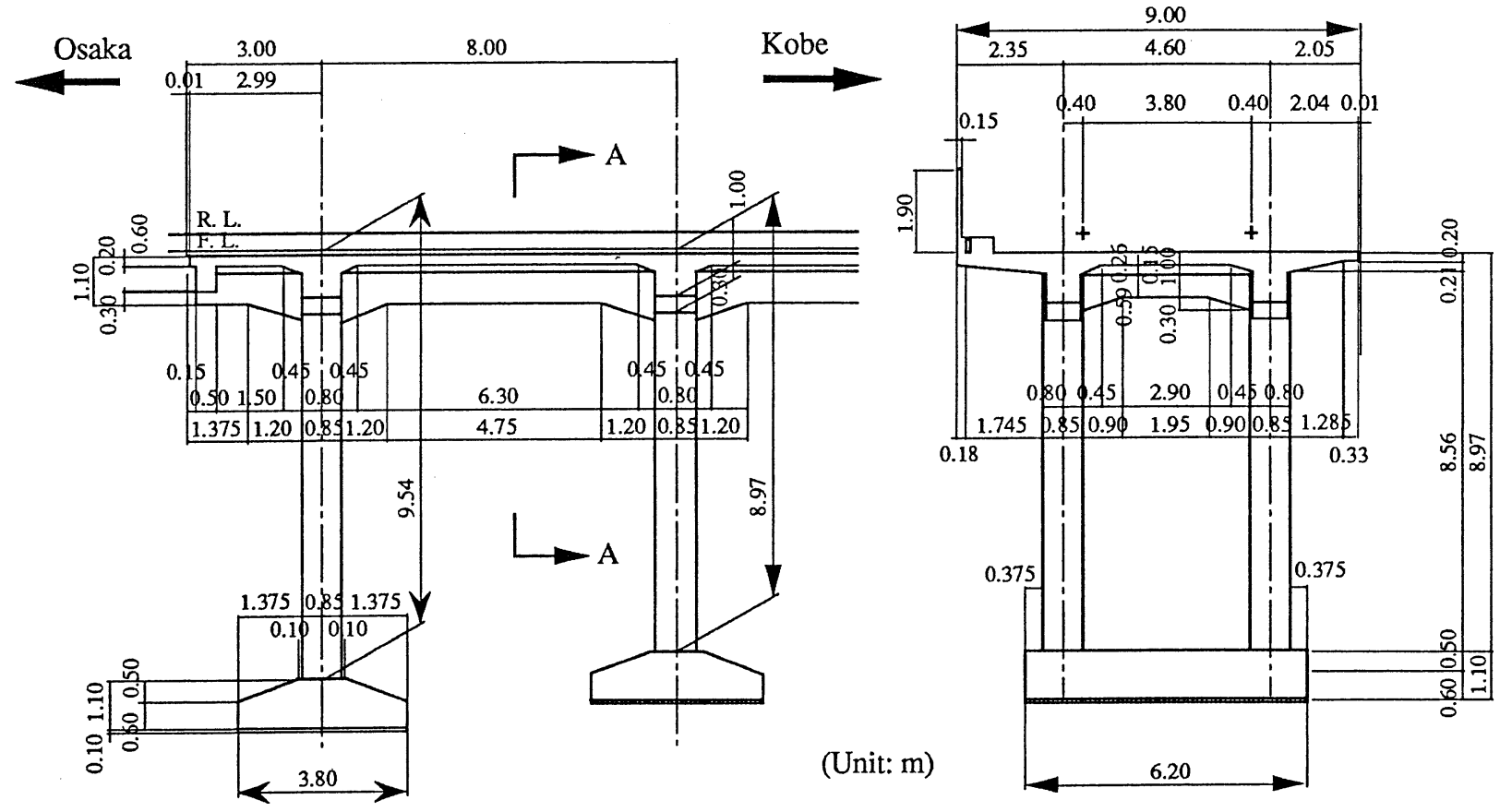

Fig. 5. Typical structures of elevated bridges (JR-Tokaido line), (a) old elevated bridge (Ikutagawa Sannomiya section), (b) new elevated bridge (Yuminoki elevated bridge) 
frame, and they are founded on footing connected with underground beams. The pile foundation is partially used. The span of the old elevated bridge between two piers is small in the longitudinal direction, and the haunch on the joining section between slab and pier is large.

The subsoils in the Sumiyoshi $\sim$ Nada area comprise silt and sand, containing a lot of boulders. The $N$ value is about 5 10 from the ground surface to $5 \mathrm{~m}$ depth and $N=20$ from $10 \mathrm{~m}$ to $20 \mathrm{~m}$ below ground level, if boulders are not encountered. Ground water is about $-1 \mathrm{~m} \sim-3$ $\mathrm{m}$ on the Nada side and $-10 \mathrm{~m}$ on the Sumiyoshi side. At the mid-point of the elevated bridge section, there is a $0.3 \mathrm{~km}$ area including Ishiya-river, in which the foundation is small diameter cast-in-place piles. Based on the degree of damage, no much difference was observed between the two different foundation systems. Damage did occur at the top and right above ground surface of the pier, with inclination in the middle elevation. Such failure patterns were most frequently observed regardless of the type of foundation.

The piers were repaired by coating with a $6 \mathrm{~mm}$ steel plate and grouting with non-contracting mortar. After the repair of the superstructure, impulse tests were carried out on the elevated bridge, and it was found from the responding frequency that the stiffness of the entire structure was adequate. For the railway at grade (from Sumiyoshi to Osaka), no serious damage occurred.

\section{HANKYU RAILWAY}

The Hankyu railway passes south of the foot of Rokko mountain. In the area $3.0 \mathrm{~km}$ east of Sannomiya station to Ohjikoen station, it was constructed as a RC rigid frame elevated bridge in 1936. The damage in this area was small. The next $3.5 \mathrm{~km}$ to the east from Ohjikoen station to Mikage station is a railway at grade, therefore, the damage was also small.

The railway extended to the east and passes across Sumiyoshi river. The river had a severe flood in 1938 and its bed was raised about $4 \mathrm{~m}$. For this reason, the approach to the bridge across the river had to be raised to 8 $\mathrm{m}$. The slope of the embankment is stabilized with a leaning-type retaining wall. During the earthquake, the top of the embankment moved with a maximum value of $0.75 \mathrm{~m}$ along a span of about $0.5 \mathrm{~km}$, and it became unstable. In the rehabilitation, the embankment was completely removed. A new trench-shaped RC structure was constructed, with foam mortar grouted into the trench to reduce its weight.

In the $1.6 \mathrm{~km}$ area from Shukugawa station (about 14 $\mathrm{km}$ east from the Sannomiya station) to Nishinomiya Kitaguchi station, the railway was constructed as a elevated bridge in 1967 and its cross section is shown in Fig. 6 . Since the double tracks at grade were elevated independently, the elevated bridge was a two-parallel single track type supported by a single pier. No connection existed between the two parallel bridges. The foundation, as shown in the figure, was composed of 5 cast-in-place piles. During the earthquake, the northern side of the railway bridge completely collapsed for a length of $0.35 \mathrm{~km}$ (Photo. 4).

As for the repair, the elevated bridge, including the

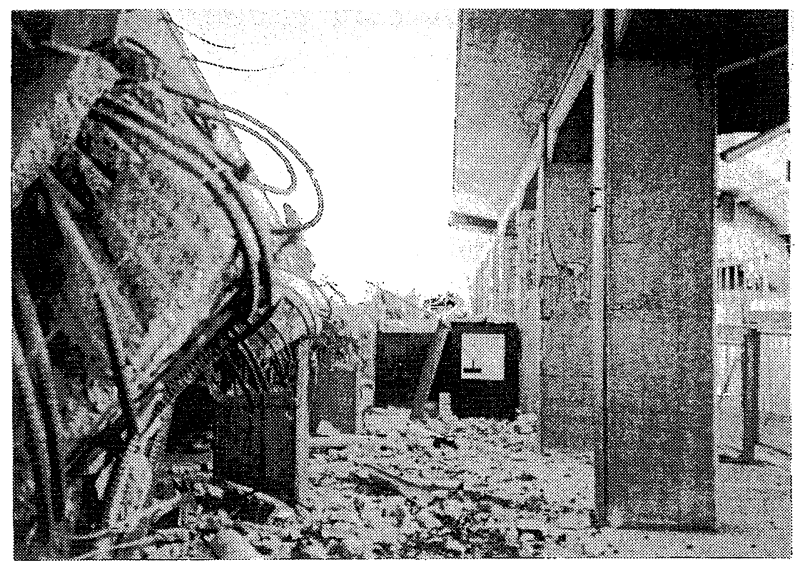

Photo. 4. Complete collapse of railway bridge in north side (Hankyu railway)

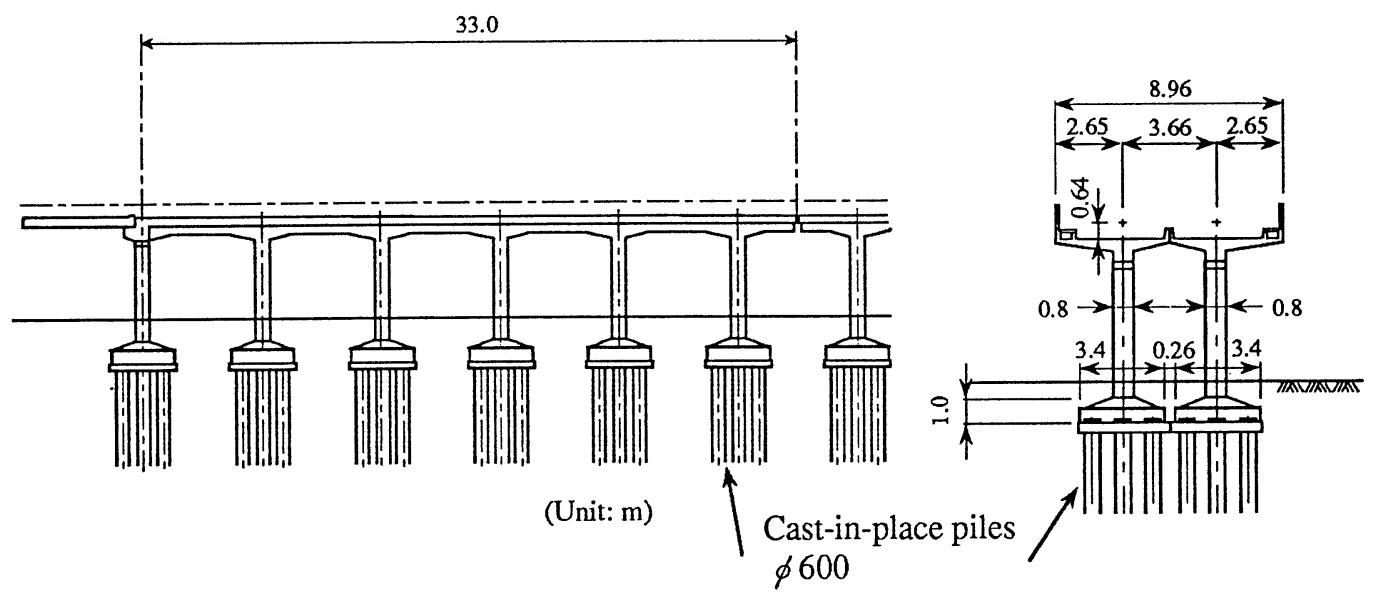

Fig. 6. Damaged two-parallel single track bridges supported on single piers (Hankyu railway, Shukugawa Nishinomiya-Kitaguchi) 
Elevation of reconstructed bridge

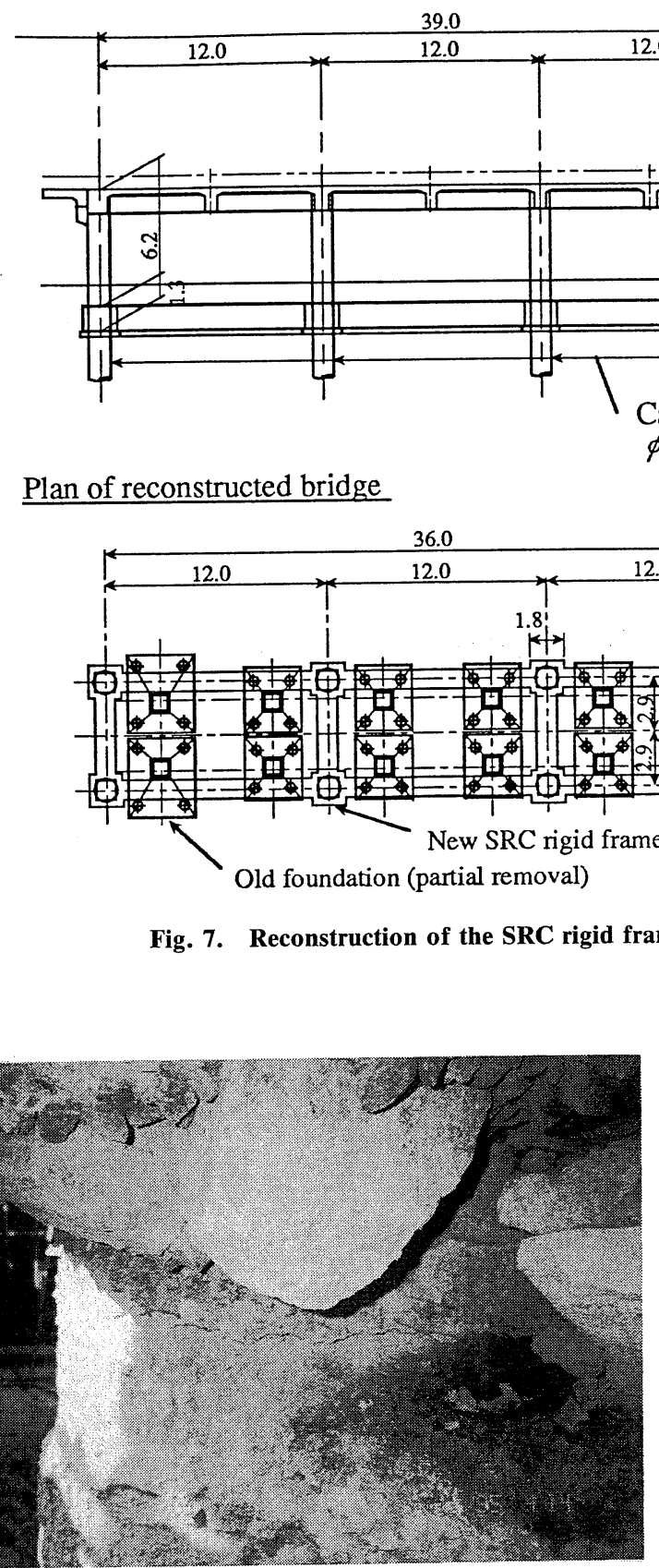

Photo. 5. Horizontal cracks at the top of the piles (Hankyu railway)

one on the south side which did not collapse, were removed while the foundation were maintained in place. A new continuous SRC (Steel Reinforced Concrete) rigid frame was constructed as shown in Fig. 7. In this figure, the newly constructed foundation is connected with an SRC underground beam. If the old foundation obstructed the new construction, then it was removed. Part of the foundations were excavated to the pile cap. It was found that horizontal cracks exist frequently as shown in Photo. 5. Photograph 6 shows a crack occurring in one section of the footing.
Cross section of reconstructed bridge

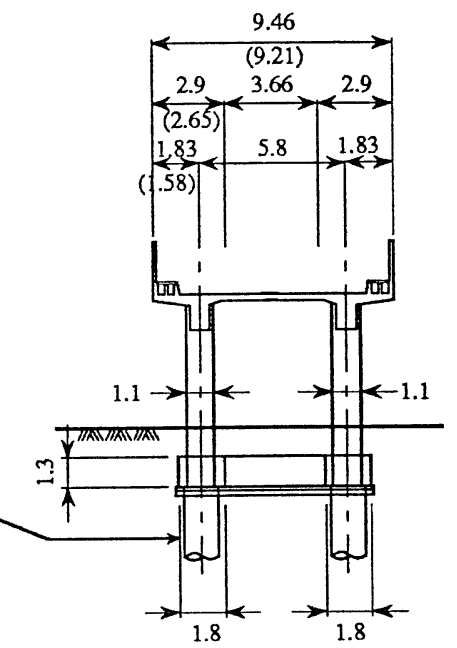

(Unit: m)

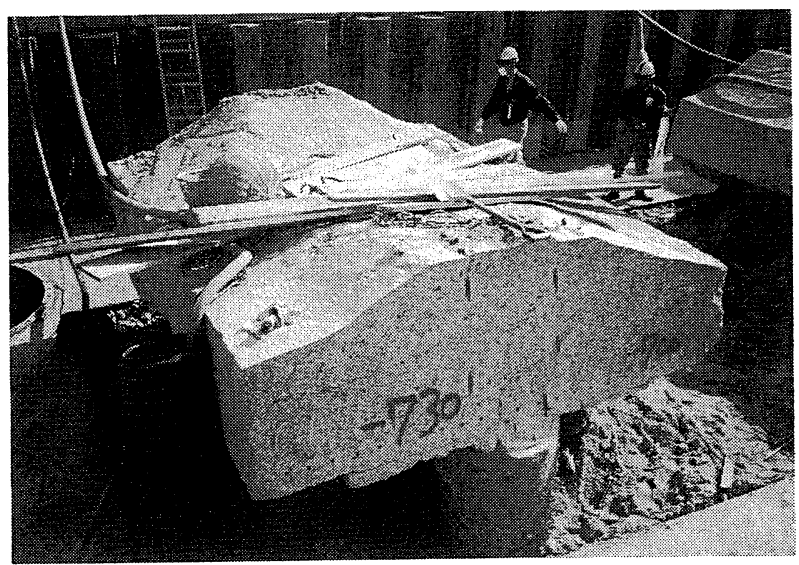

Photo. 6. Cracks in the footing cross section (Hankyu railway)

\section{JR-SANYO-SHINKANSEN}

The JR-Sanyo-Shinkansen railway shown in Fig. 1 started operation in 1972. It passes through inland area. The damaged bridge sites are located along a length of $43 \mathrm{~km}$ between Kobe Nishi ward and Amagasaki City as shown in Table 1 . Especially in the $1 \mathrm{~km}$ area near the east entrance of Rokko Tunnel, most of the bridge damage occurred. The structure of the elevated bridge, as shown in Fig. 8, is mainly 3-span RC rigid frame. A twolayer RC rigid frame or rigid-frame pier plus PC crossbeam also exist. Typically the piers are founded on piles, 
Table 1. Section of serious damage for the elevated bridge of JR-Sanyo-Shinkansen

\begin{tabular}{|c|c|c|c|c|}
\hline $\begin{array}{l}\text { Distance from } \\
\text { Tokyo St. }(\mathrm{km})\end{array}$ & Name of structure & $\begin{array}{c}\text { Damage } \\
\text { (Total distance of damage) }\end{array}$ & $\begin{array}{c}\text { Foundation type } \\
\phi: \text { diameter, } L: \text { length (Unit: } \mathrm{m} \text { ) }\end{array}$ & $\begin{array}{l}\text { Geology of surface } \\
\text { layer }\end{array}$ \\
\hline 523.159 & Shimokema BL & $\begin{array}{l}\text { Fall of elevated bridge } \\
\qquad(70 \mathrm{~m})\end{array}$ & $\begin{array}{c}\text { Cast-in-place pile, One pile/One pier }(\phi 1.2 \times L 8.0) \\
\text { Height of ground beam } 1.7\end{array}$ & Alluvial clay \\
\hline 527.784 & Daiichi-noma BL & $\begin{array}{l}\text { Failure of elevated bridge } \\
\qquad(48 \mathrm{~m})\end{array}$ & Independent footing $(4 \times 4)$ & Diluvial gravel \\
\hline 528.900 & Tokitomo BL & $\begin{array}{l}\text { Fall of elevated bridge } \\
\qquad(65 \mathrm{~m})\end{array}$ & Independent footing $(8.9 \times 4.6)$ & Alluvial sand \\
\hline 529.413 & Mukogawa B & Shift of deck & Caisson $(\phi 8.0 \times L 14.0)$ & Alluvial gravel \\
\hline$*_{530.551}$ & Sakamizu BL & $\begin{array}{l}\text { Fall of elevated bridge } \\
\qquad(130 \mathrm{~m})\end{array}$ & $\begin{array}{c}\text { Cast-in-place pile, One pile/One pier }(\phi 1.2 \times L 8.0) \\
\text { Height of ground beam } 1.7\end{array}$ & Alluvial sand \\
\hline$*_{530.874}$ & Koutouen BL & Fall of deck $(40 \mathrm{~m})$ & $\begin{array}{c}\text { Cast-in-place pile, One piles/One pier }(\phi 1.2 \times L 8.0) \\
\text { Height of ground beam } 1.5\end{array}$ & Alluvial sand \\
\hline *530.990 & $\begin{array}{l}\text { Hankyu- } \\
\text { imazusen BL }\end{array}$ & Fall of deck $(80 \mathrm{~m})$ & $\begin{array}{l}\text { Rigid frame }+ \text { Cast-in-place piles, } 10 \text { piles } / \text { per pier } \\
\qquad(\phi 1.2 \times L 7.0)\end{array}$ & Alluvial sand \\
\hline$*_{531.301}$ & Kannou BV & Fall of deck $(40 \mathrm{~m})$ & $\begin{array}{l}\text { Wall-type pier + Cast-in-place piles, } 5 \text { piles } / \text { per pier } \\
(\phi 1.0 \times L ?)\end{array}$ & Talus \\
\hline 566.100 & Ikawa BV & Fall of deck $(80 \mathrm{~m})$ & Special pile, 99 pile group $(\phi 0.35 \times L 8.0)$ & Alluvial sand \\
\hline 571.880 & Taniyagigawa $\mathrm{B}$ & $\begin{array}{l}\text { Getting out of deck } \\
\text { (1 site) }\end{array}$ & $\begin{array}{c}\text { Rigid frame }+ \text { Cast-in-place piles, } 16 \text { piles } / \text { per pier } \\
(\phi 0.98 \times L 13.0)\end{array}$ & Alluvial sand \\
\hline
\end{tabular}

*Section in which damage was concentrated

Elevation

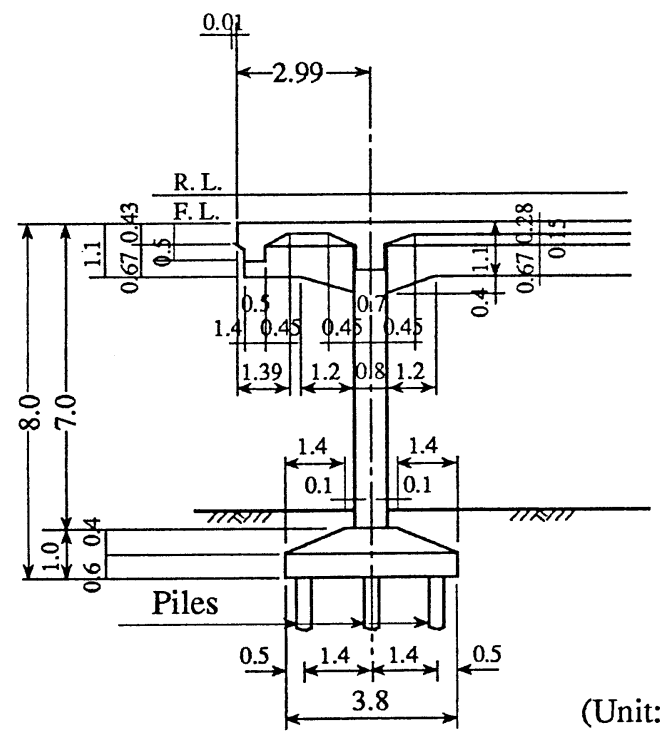

\section{Cross section}

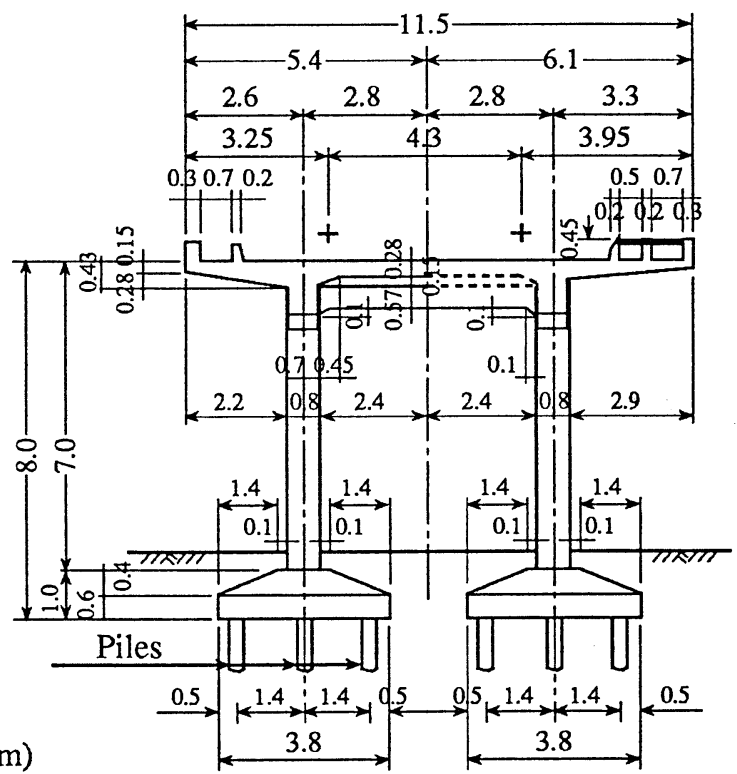

Fig. 8. Damaged 3-span RC rigid frame (JR-Sanyo-Shinkansen)

while spread footings are also used depending on the soil conditions. The size of the footing and existence of an underground beam are also determined by the subsurface conditions. Table 1 shows the type of the foundation where severe damage occurred on the railway bridges. From the table, it is hard to say which type of superstructure or foundation are more vulnerable. Photograph 7 shows an example of damage and Fig. 9 shows the design drawing for the elevated bridge.

Since the railway passes through various geologic areas, the relationship between the damage and geologic condition could be investigated. As shown in Table 1, most bridges that had undergone damage are located in areas underlying alluvial sand. Within the $49 \mathrm{~km}$ length 

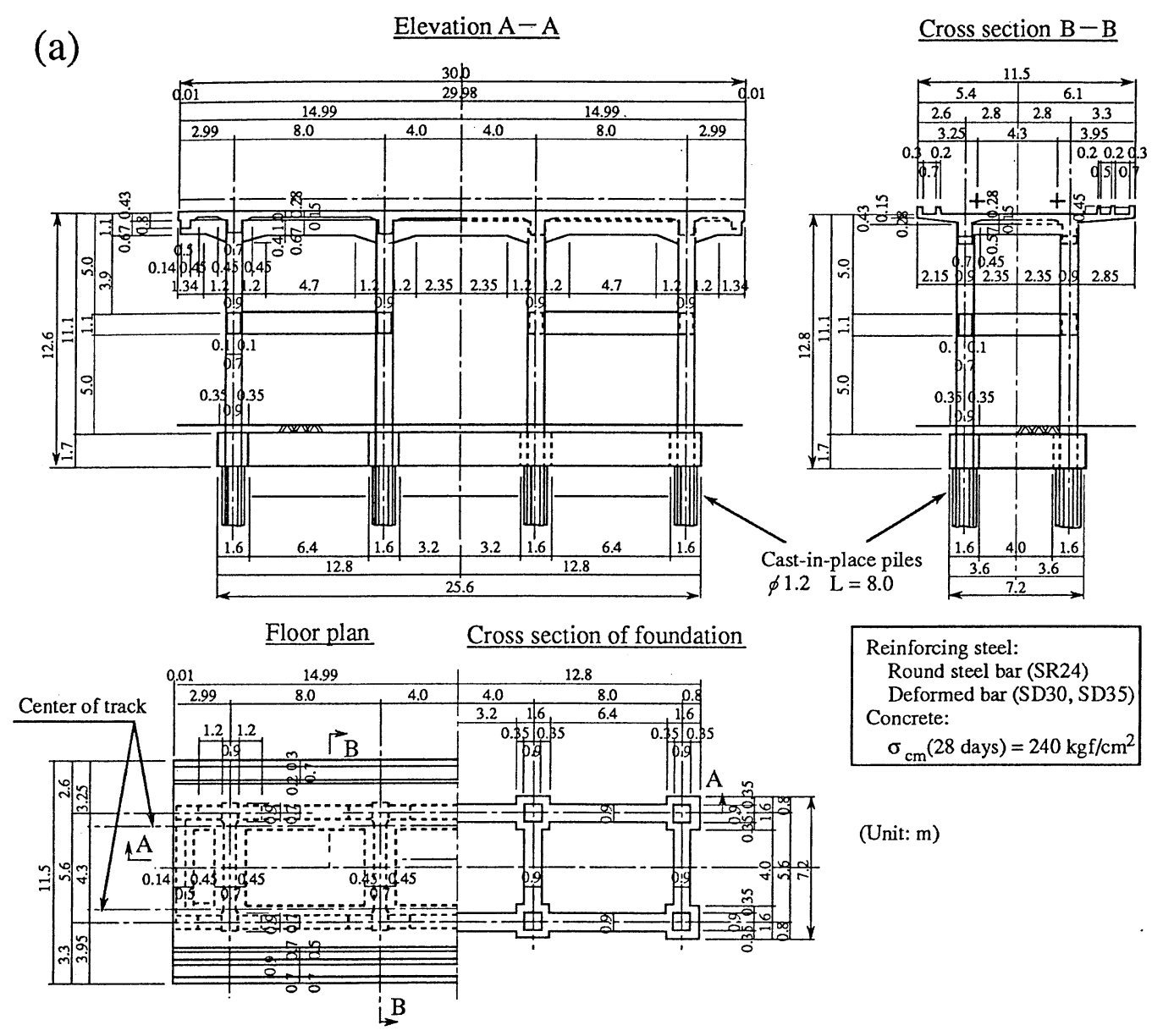

(Unit: m)

(b)

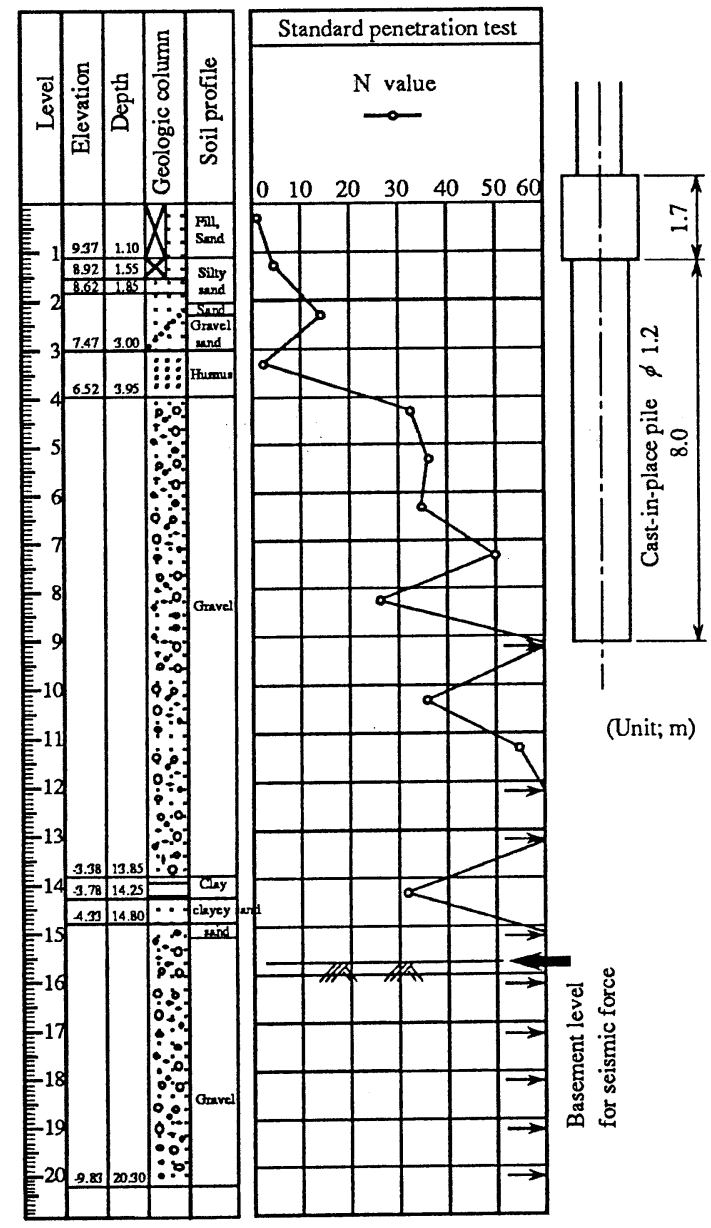

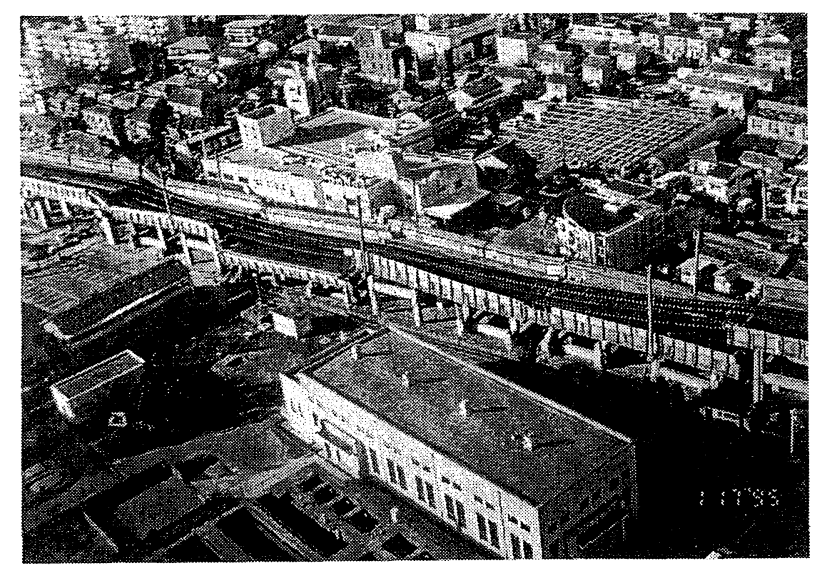

Photo. 7. Example of the damage on the elevated bridge (JR-SanyoShinkansen)
Fig. 9. Elevated bridge and the foundation (JR-Sanyo-Shinkansen, Sakamizu-elevated bridge): (a) design drawing; (b) soil boring log and pile foundation 
shown in Table 1 , only $18 \mathrm{~km}$ is elevated bridge, where $32 \%$ is on alluvial sand or clay.

The stiffness of the entire structure after rehabilitation was checked using same method as that for the JRTokaido and Sanyo Line.

\section{CONCLUSIONS}

The rehabilitation of the railway was an urgent concern so that only part of the investigation; focused on the foundations was carried out in the area where damage of the superstructure was slight. Based on the investigation of the spread foundations, it was found that large movement and failure in a footing did not occur, whereas damage in the connection between footing and pier was found in many places. Cracks were frequently found in the pile foundations of a bridge supported on one-pier. Therefore, if repair and rehabilitation is not carried out for these foundations, it is necessary to clearly define the safety factor for the structure, based on a long-term observations of displacement and vibration in the superstructure.

\section{ACKNOWLEDGMENTS}

The authors would like to express their appreciation to those persons in JR Nishi-nihon, Hanshin Line and Hankyu Line for their kind assistance. 